\title{
Microstructure and Rheological Properties of Iranian White Cheese Coagulated at Various Temperatures
}

\author{
A. Madadlou, ${ }^{\star 1}$ A. Khosroshahi, ${ }^{\star}$ S. M. Mousavi,† and Z. E. Djome \\ *Urmia University, Food Science and Engineering, Urmia, Iran \\ †Tehran University, Food Science and Engineering, Karadj, Iran
}

\begin{abstract}
The effect of milk coagulation temperature on the composition, microstructure monitored using scanning electron micrographs, opacity measured by a Hunter lab system, and rheological behavior measured by uniaxial compression and small amplitude oscillatory shear were studied. Three treatments of Iranian White cheese were made by applying coagulation temperatures of 34,37 , and $41.5^{\circ} \mathrm{C}$ during the cheese-making procedure. A higher coagulation temperature resulted in increased fat and protein contents, and decreased the moisture content and ratio of moisture to protein. The highest temperature $\left(41.5^{\circ} \mathrm{C}\right)$ had a significant effect on the opacity of Iranian White cheese. Milk coagulation at this temperature decreased the whiteness index (Hunter L value) and increased the yellowness index (Hunter $b$ value) of the aged product compared with cheeses coagulated at lower temperatures. Microstructure of the cheese coagulated at $41.5^{\circ} \mathrm{C}$ was more compact and undisturbed, reflecting the higher values of stress at fracture and storage modulus measured for this treatment.
\end{abstract}

Key words: Iranian White cheese, microstructure, rheology, opacity

\section{INTRODUCTION}

Iranian White cheese is a close-textured brined cheese, resembling Beyaz peynir (Turkish White cheese) and Feta, although it differs from Feta in the way it is made. It is manufactured without dry salting of curd and slime formation on the curd surface before brining, both of which are essential for the development of the characteristic Feta flavor during ripening (Carić, 1993). At the industrial level, the ripening period is 40 to $90 \mathrm{~d}$, but cheeses made from raw milk in small rural production units may be ripened for 6 to 8 mo (Azarnia et al., 1997). It is widely consumed all over the country

Received January 12, 2006.

Accepted February 28, 2006

${ }^{1}$ Corresponding author: ashkan.madadlou@gmail.com as a breakfast cheese, and is used in the manufacture of other domestic cheese varieties such as jug cheese. The long-ripened cheese may soften drastically due to extended proteolysis that decreases the surface area occupied by the protein fraction in cheese microstructure, leading to a decrease of the force-bearing component in cheese texture (Khosroshahi et al., 2006), and a gradual breakage of the network calcium bonds (Ehsani et al., 1999). The latter is because of the slow solubilization of remaining colloidal calcium phosphate during aging (Lucey et al., 2003).

Cheese texture may be defined as a composite of sensory attributes resulting from a combination of physical properties perceived by the sense of sight, touch, and hearing (Fox et al., 2000). The rheology of cheese is a function of its composition, microstructure (i.e., the structural arrangement of the components), the physicochemical state of its components such as the ratio of solid fat to liquid fat, and its macrostructure, which reflects the presence of heterogeneities such as curd granule junctions, cracks, and fissures (Gunasekaran and Ak, 2003). A number of factors, both compositional and process parameters, are known to influence texture of cheese (Wium et al., 2003). Milk coagulation, the initial step in the manufacturing of many dairy products (Castillo et al., 2006) including cheese, can be expected to determine the structural organization of the components in cheese gel. In rennet-induced curds, coagulation phenomenon is greatly influenced by type of rennet (Esteves et al. 2003), concentration of rennet (Wium and Qvist, 1998; Wium et al., 2003; Madadlou et al., 2005), temperature (Esteves et al., 2003; Wium et al., 2003), and time at coagulation temperature (Wium et al., 2003), among other factors.

Despite the importance of coagulation temperature in the cheese-making process, there are no reports on the effect of gelation temperature on the textural properties of Iranian White cheese. The object of the present paper was to study the influence of milk coagulation temperature on the rheology (measured in uniaxial compression and small amplitude oscillatory shear), microstructure (monitored using scanning electron micrographs), color (determined by a Hunter lab system), 
and chemical characteristics of Iranian White cheese at the end of $90 \mathrm{~d}$ of ripening in brine.

\section{MATERIALS AND METHODS}

\section{Treatments, Cultures, and Rennet}

Three treatments of cheese were made as follows: cheese coagulated at $34^{\circ} \mathrm{C}$, cheese coagulated at $37^{\circ} \mathrm{C}$, and cheese coagulated at $41.5^{\circ} \mathrm{C}$. Cheese batches were manufactured using $7 \mathrm{~kg}$ of milk for each treatment. Cheeses were manufactured in triplicate, with each replicate being manufactured on $1 \mathrm{~d}$. One lyophilized direct-to-vat mesophilic mixed culture (R-704, Chr. Hansen Dairy Cultures, Hoersholm, Denmark), containing Lactococcus lactis ssp. cremoris and Lactococcus lactis ssp. lactis, was used as starter at a ratio of $0.04 \mathrm{~g}$ of starter/L of milk. As coagulant, chymosin derived by fermentation of Aspergillus niger var. awamori (ChyMax standard rennet, 183 International Milk Clotting Units (IMCU)/mL; Chr. Hansen Inc.; International Dairy Federation, 1997) was used at a concentration of 4.5 IMCU/kg of milk. Rennet was diluted 30 -fold with cold water, and then added to each 7-kg batch of milk.

\section{Cheese-Making Procedure}

Fresh raw milk obtained from the Animal Husbandry department of Urmia University (Urmia, Iran), was batch-pasteurized at $65^{\circ} \mathrm{C}$ for 5 min (Hayaloglu et al., 2002) in a stainless steel container placed in a water bath, cooled to $35^{\circ} \mathrm{C}$, and transported to a cheese vat (FT20-MkII cheese vat, Armfield Ltd., Ringwood, Hampshire, UK). The milk was supplemented with 0.15 $\mathrm{g}$ of $\mathrm{CaCl}_{2} / \mathrm{kg}$ of milk, and held at $34^{\circ} \mathrm{C}$ for approximately 60 min after inoculation of culture for starter maturation before the addition of rennet. The curd was cut crosswise into $2-\mathrm{cm}^{3}$ cubes when firm (after approximately $55 \mathrm{~min}$ ). After being cut, the curd was allowed to settle for 3 to $5 \mathrm{~min}$, and was then gently agitated at a gradually increasing rate for $10 \mathrm{~min}$ to avoid fusion of freshly cut curd cubes, and to facilitate whey expulsion. This was followed by whey draining and pressing the transferred curd into molds $(14 \mathrm{~cm} \times 13 \mathrm{~cm} \times 25$ $\mathrm{cm}$ ) for $2.5 \mathrm{~h}$ (under gradually increasing pressure up to approximately $2.9 \mathrm{MPa}$ at the first hour) to complete draining. After pressing, the curd was cut in blocks (4 $\mathrm{cm} \times 6 \mathrm{~cm} \times 6 \mathrm{~cm})$. The blocks were stored at 23 to $25^{\circ} \mathrm{C}$ for 19 to $20 \mathrm{~h}$, placed in airtight plastic containers, and covered with $13 \%$ brine (brine was pasteurized beforehand at $80^{\circ} \mathrm{C}$ for $10 \mathrm{~min}$, filtered through a clean cloth after rapid cooling, and adjusted to $\mathrm{pH} 4.65$ by addition of $99 \%$ lactic acid). After sealing, the containers were stored first at 23 to $25^{\circ} \mathrm{C}$ for $24 \mathrm{~h}$, and then at 5 to $6^{\circ} \mathrm{C}$ for the 90-d ripening period.

\section{Chemical Analysis}

Titratable acidity of milk was determined by the Dornic method, and total solids were determined by drying 8 to $11 \mathrm{~g}$ of milk at $100^{\circ} \mathrm{C}$ for $5 \mathrm{~h}$. The $\mathrm{pH}$ of milk was measured using a digital $\mathrm{pH}$ meter (microprocessor $\mathrm{pH}$ meter, model pH 537, WTW, Weilheim, Germany). Cheese was analyzed for moisture content by vacuum oven (AOAC, 1997; method number 926.08), and for ash content by the dry ash method (AOAC, 1997; method number 935.42). The fat content of milk and cheese samples was determined by the Gerber method and their total protein contents were determined by measuring total nitrogen using the Kjeldahl method (AOAC, 1997; method number 920.123), and converting it to protein content by multiplying by 6.38 . All chemical measurements were done in triplicate or more. Cheese samples were chemically analyzed on d 87 of ripening.

\section{Color Analysis}

The color of 90-d-old samples was quantitatively determined using a Hunter lab colorimeter system (Hunter Lab, DP-9000, Hunter Associates Laboratory, Inc., Reston, VA), in which $\mathrm{L}$ and $\mathrm{b}$ values correspond to whiteness and yellowness, respectively. Color measurements were performed in triplicate for each treatment at different sites.

\section{Microstructure}

Cheese samples were prepared for scanning electron microscopy on $\mathrm{d} 87$ of ripening following the method of Drake et al. (1996) as modified by Madadlou et al. (2005), except that the samples were immersed in $2.5 \%$ glutaraldehyde fixative (Merck Science, Darmstadt, Germany) overnight. Samples were viewed by scanning electron microscope (XL Series, model XL30, Philips, Eindhoven, The Netherlands) operated at $20.0 \mathrm{kV}$. Photomicrographs were recorded at 2,500 $\times$ magnification, and globally modified by ACD Photo editor software, version 3.1 (Software Spectrum UK Ltd., High Wycombe, UK) to isolate the important details (holes) from the background (Russ, 2005) by increasing the contrast to $>95 \%$ and brightening the picture with gamma adjustment. The Corel Photo-Paint 7 software (Corel Corporation, Ottawa, Canada) was then used to measure the largest inscribed circle (Russ, 2005) in the randomly selected holes distributed at the microstructure.

\section{Rheological Analyses}

Uniaxial Compression. The simplest fundamental test, uniaxial compression (Tunick, 2000), was performed at d 90 of ripening using an HTE Universal 
Table 1. Means ( \pm SD) of chemical composition and whiteness (Hunter L and b values) of Iranian White cheeses coagulated at different temperatures

\begin{tabular}{|c|c|c|c|c|}
\hline & \multirow[b]{2}{*}{ Milk } & \multicolumn{3}{|c|}{ Coagulation temperature } \\
\hline & & $34^{\circ} \mathrm{C}$ & $37^{\circ} \mathrm{C}$ & $41^{\circ} \mathrm{C}$ \\
\hline Moisture (\%) & $88.9 \pm 0.31$ & $53.61 \pm 0.29^{\mathrm{a}}$ & $51.16 \pm 0.41^{b}$ & $48.98 \pm 0.22^{\mathrm{c}}$ \\
\hline Fat $(\%)$ & $3.31 \pm 0.12$ & $22.6 \pm 0.2^{\mathrm{c}}$ & $23.6 \pm 0.1^{\mathrm{b}}$ & $24.2 \pm 0.2^{\mathrm{a}}$ \\
\hline $\mathrm{pH}$ & $6.67 \pm 0.01$ & - & - & - \\
\hline Protein $(\%)$ & $3.06 \pm 0.01$ & $15.98 \pm 0.13^{\mathrm{c}}$ & $17.14 \pm 0.21^{b}$ & $19.05 \pm 0.18^{\mathrm{a}}$ \\
\hline $\mathrm{M}: \mathrm{P}^{1}$ & - & 3.35 & 2.98 & 2.57 \\
\hline Total ash (\%) & - & $6.91 \pm 0.01^{\mathrm{a}}$ & $6.92 \pm 0.02^{\mathrm{a}}$ & $6.91 \pm 0.01^{\mathrm{a}}$ \\
\hline $\mathrm{L}$ value & - & $52.41 \pm 0.29^{\mathrm{a}}$ & $52.29 \pm 0.35^{\mathrm{a}}$ & $51.17 \pm 0.31^{\mathrm{c}}$ \\
\hline $\mathrm{b}$ value & - & $5.11 \pm 0.10^{\mathrm{b}}$ & $5.18 \pm 0.13^{\mathrm{b}}$ & $6.19 \pm 0.11^{\mathrm{a}}$ \\
\hline
\end{tabular}

${ }^{a-c}$ Means within the same row with different superscript differ significantly $(P<0.05)$.

${ }^{1}$ Ratio of moisture to protein, calculated using the means of moisture and protein.

Testing Machine (S-Series Bench UTM model H5K-S, Hounsfield Test Equipment Ltd., Redhill, UK) following the method of Madadlou et al. (2005) except that cheese blocks were cut into cylinders (18.8 $\mathrm{mm}$ diameter and $9.8 \mathrm{~mm}$ high), and samples were compressed uniaxially with $61.2 \%$ deformation (test end-point: $6 \mathrm{~mm}$ ) from the initial height of the sample in one bite. Samples were taken from at least $1 \mathrm{~cm}$ deep in cheese blocks, and placed immediately in airtight containers to prevent dehydration (Madadlou et al., 2005). Samples were equilibrated to room temperature $\left(22 \pm 1^{\circ} \mathrm{C}\right)$ for at least $4 \mathrm{~h}$ before testing. Calculated parameters were stress $\left(\sigma_{\mathbf{f}}\right)$ and Hencky strain $\left(\varepsilon_{\mathbf{h}}\right)$ at fracture (Madadlou et al., 2005).

Dynamic Rheological Measurements. Small amplitude oscillatory shear measurements were performed with a Universal Dynamic Spectrometer, Paar Physica UDS 200 rheometer (Physica Messtechnik GmbH, Stuttgart, Germany). The measuring geometry consisted of 2 parallel plates with a diameter of $25 \mathrm{~mm}$ and 1-mm gap size (sample thickness). Samples were cut at least $1 \mathrm{~cm}$ deep into the cheese blocks at $6^{\circ} \mathrm{C}$. These samples were immediately placed in small airtight plastic containers and equilibrated at room temperature $\left(22 \pm 1^{\circ} \mathrm{C}\right)$ for at least $4 \mathrm{~h}$. Excessive cheese was trimmed of carefully with a razor blade, and the sample allowed to rest for $10 \mathrm{~min}$ on the rheometer to allow stresses induced during sample handling to relax. Frequency was set at $10 \mathrm{~Hz}$ and the amplitude was varied between 0.01 to $2.5 \%$ in 20 steps resulting in a strain sweep test.

The parameter calculated was the storage modulus $\left(\mathbf{G}^{\prime}\right)$, which is a measure of elasticity (Steffe, 1996). Values are the averages of 2 measurements for 3 replicates of each cheese. All rheological measurements were performed on d 89 and 90 of ripening. Each cheese was analyzed in triplicate.

\section{Statistical Analyses}

The experiment was replicated 3 times in a complete randomized design. The ANOVA was carried out using the PROC GLM of SAS (Version 8.2, SAS Institute, Inc., Cary, NC) to determine the differences between data means at $5 \%$ significant level.

\section{RESULTS AND DISCUSSION}

\section{Composition and Opacity of Cheese}

The chemical characteristics of the milk used for cheese manufacture and those of cheese treatments are reported in Table 1. As the milk coagulation temperature increased, the fat and protein contents of cheese increased, whereas moisture content significantly $(P<$ $0.05)$ decreased. The higher the coagulation temperature, the higher the fat and protein contents, and the lower the moisture content. The treatment; therefore, led to a significant decrease in the ratio of moisture to protein (M:P). Fat and moisture act as the filler in the casein matrix of cheese texture (Rudan et al., 1999). When the moisture content was decreased due to the increased coagulation temperature, the fat did not replace the moisture on an equal basis so the total filler volume was decreased.

The highest temperature $\left(41.5^{\circ} \mathrm{C}\right)$ had a significant effect on the opacity of Iranian White cheese. Milk coagulation at this temperature decreased the whiteness index (Hunter L value) and increased the yellowness index (Hunter $b$ value) of the product compared with cheeses coagulated at lower temperatures. The effect of the intermediate temperature $\left(37^{\circ} \mathrm{C}\right)$ on opacity of cheese was not statistically significant (Table 1). The scattering of light by any system is related to its heterogeneity at the molecular (Pastorino et al., 2002) and microstructural levels. In a solid material such as cheese, light penetrates the superficial layers and is 
Table 2. Mean $( \pm \mathrm{SD})$ of uniaxial compression parameters for 90 -d-old Iranian White cheese coagulated at different temperatures

\begin{tabular}{|c|c|c|c|}
\hline & \multicolumn{3}{|c|}{ Coagulation temperature } \\
\hline & $34^{\circ} \mathrm{C}$ & $37^{\circ} \mathrm{C}$ & $41.5^{\circ} \mathrm{C}$ \\
\hline $\begin{array}{l}\text { Fracture stress }(\mathrm{kPa}) \\
\text { Fracture strain }\end{array}$ & $\begin{aligned} 60.86 & \pm 21.15^{\mathrm{c}} \\
0.25 & \pm 0.02^{\mathrm{c}}\end{aligned}$ & $\begin{aligned} 173.35 & \pm 26.46^{\mathrm{c}} \\
0.34 & \pm 0.02^{\mathrm{b}}\end{aligned}$ & $\begin{aligned} 186.99 & \pm 27.34^{\mathrm{a}} \\
0.54 & \pm 0.01^{\mathrm{a}}\end{aligned}$ \\
\hline
\end{tabular}

${ }^{\text {ac }}$ Means within the same row with different superscript differ significantly $(P<0.05)$.

scattered mainly at the interfaces of milk fat globules (Lemay et al., 1994) and the edges of whey pockets (Paulson et al., 1998). The higher milk coagulation temperatures decreased the moisture content and the M:P (Table 1), and changed the branched, interlaced microstructure to a dense one (Figure 1), leading to a decreased surface area occupied by light scattering centers and more molecular homogeneity.

\section{Rheological Properties and Microstructure}

The effect of the coagulation temperature on the rheological parameters is seen in Table 2 and Figure 2. Fracture stress and $G^{\prime}$, which correlated well with the sensory firmness of Iranian White cheese (Madadlou et al., 2005), increased with coagulation temperature. The fracture strain $\left(\varepsilon_{\mathrm{h}}\right)$ significantly increased, probably because the increased coagulation temperature tended to make the gel longer in texture. In agreement with our results, Khosroshahi et al. (accepted) reported that the firmer Iranian White cheeses were also longer (had higher Hencky strain at fracture). A similar result of coagulation temperature on $\sigma_{\mathrm{f}}$ has been reported for 2d-old fat-free Feta cheese made from ultrafiltered milk using direct acidification by glucono- $\delta$-lactone (Wium et al., 2003). The magnitude of $\sigma_{\mathrm{f}}$ and $\mathrm{G}^{\prime}$ values depends on the number and strength of bonds between casein particles and on the structure and spatial distribution of strands of casein in the gel network (Esteves et al., 2003). A higher coagulation temperature increases the aggregation rate (Dalgleish, 1993), which in turn affects the initial mode of aggregates of casein particles, leading to a denser or coarser network structure and firmer texture (Wium and Qvist, 1998). Hydrophobic interactions, which influence the aggregation of casein particles, are favored at higher temperatures. The higher coagulation temperature may have stiffened the junctions (Vétier et al., 2003), leading to dense aggregates. In addition, after a gel has been formed, collisions between casein micelle aggregates and network strands lead to further aggregation (Lomholt and Qvist, 1997) and a coarsening of the network (Madadlou et al., 2005). This process progressively strengthens the links between micelles (Green et al., 1978) and increases the rheological modulus (Lomholt and Qvist, 1997). It appears that the rate of gel firming or network congestion caused by rearrangement is increased as the temperature of coagulation is increased (Esteves et al., 2003; Wium et al., 2003).
A)

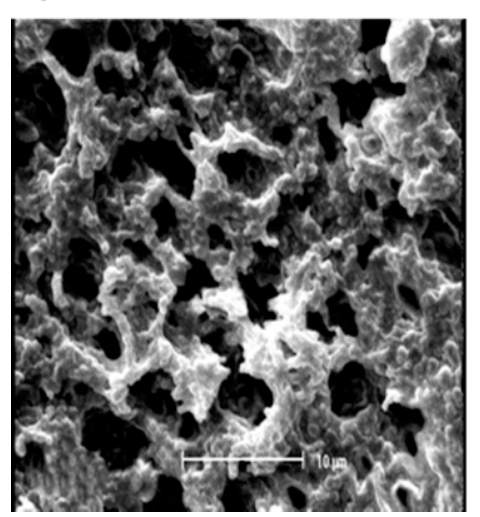

B)

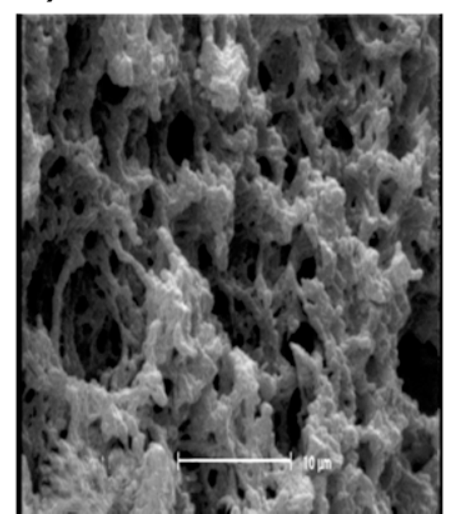

C)

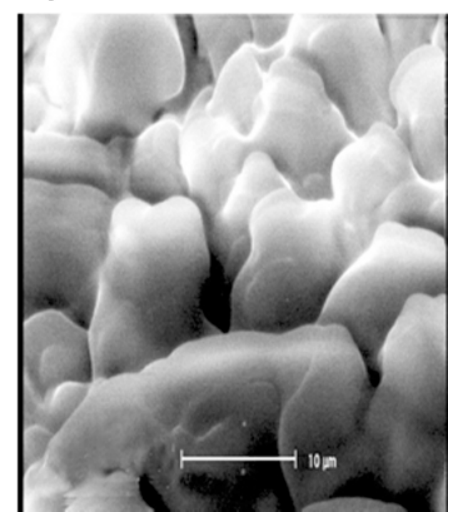

Figure 1. Scanning electron micrographs of 87 -d-old Iranian White cheese: A) cheese coagulated at $34^{\circ} \mathrm{C}$ shows a continuous casein network permeated by holes and fissures corresponding to discrete fat globules and pools of coalesced fat globules; B) cheese coagulated at $37^{\circ} \mathrm{C}$; C) cheese coagulated at $41.5^{\circ} \mathrm{C}$ shows that the casein matrix is more compact, dense, and undisturbed, reflecting the extensive elastic character observed for the treatment. 


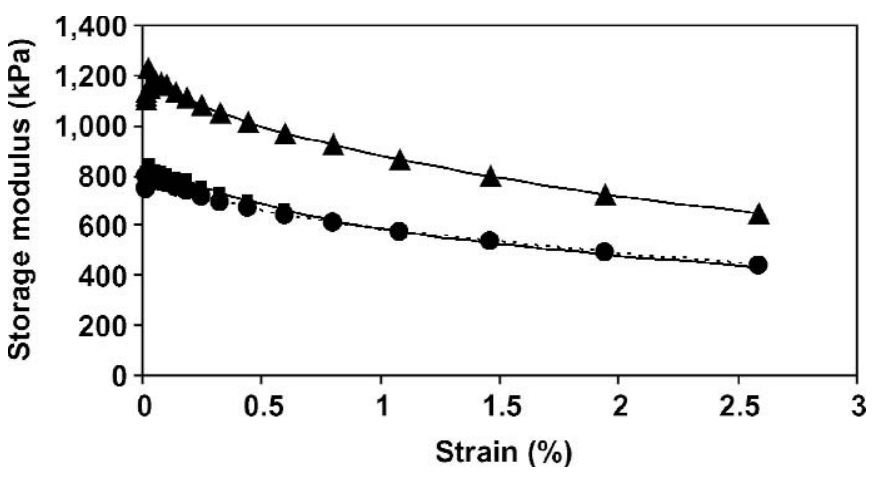

Figure 2. Storage modulus of Iranian White cheese: cheese coagu-

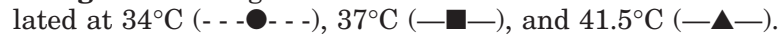

Globally modified (Russ, 2005) scanning electron micrographs of 87-d-old Iranian White cheese coagulated at $34^{\circ} \mathrm{C}$ (Figure 1) showed the continuous casein network permeated by holes and fissures corresponding to discrete fat globules and pools of coalesced fat globules. Microstructure of the cheese coagulated at $41.5^{\circ} \mathrm{C}$ (Figure 1) was clearly different from that of cheeses coagulated at lower temperatures $\left(34\right.$ and $\left.37^{\circ} \mathrm{C}\right)$ in that its casein matrix was more compact and undisturbed. The average diameters of the largest inscribed circles in the randomly selected voids were $3.1,1.9$, and $1.4 \mu \mathrm{m}$ for cheeses coagulated at 34,37 , and $41.5^{\circ} \mathrm{C}$, respectively. Although the surface area occupied by the voids in the microstructure of the treatments was not numerically measured, there was a clear reduction in the contribution of fat (holes) to the microstructure of cheese coagulated at $41.5^{\circ} \mathrm{C}$. Fat and moisture act as the filler in the casein matrix of cheese texture (Rudan et al., 1999), and give it lubricity and softness. The casein matrix provides the elastic character to cheese texture. The decreased moisture content (Kaya, 2002) and increase in the volume fraction of the force-bearing component (protein) in cheese microstructure can lead to the increased hardness (Khosroshahi et al., 2006). This probably explained the higher values of $\sigma_{\mathrm{f}}$ and $\mathrm{G}^{\prime}$ observed with the cheese coagulated at the highest temperature. A compact protein matrix in the microstructure of lowfat Iranian White cheese has been related to the extensive elastic character described by the consumer taste panel and measured by the rheological analysis (our unpublished data). Madadlou et al. (2005) proposed that coarsening/congestion of the network and increases in hardness parameters are parallel events in the texture of Iranian White cheese. The same interrelation between microstructure and rheological parameters has been reported for Feta (Wium et al., 1998; Wium and Qvist, 1998) and fat-free Feta (Wium et al., 2003) cheeses made from ultrafiltered milk. Green
(1990) similarly reported that Cheddar cheese produced from retentates treated at $90^{\circ} \mathrm{C}$ for $15 \mathrm{~s}$ had higher coarseness of network and sensory firmness when compared with cheeses produced from more concentrated but non-heat-treated retentates.

\section{CONCLUSIONS}

This study indicated that milk coagulation temperature had important effects on chemical composition, opacity, microstructure, and rheological behavior of Iranian White cheese. As the coagulation temperature increased, the moisture content and whiteness index decreased, and protein and fat contents increased. The highest coagulation temperature $\left(41.5^{\circ} \mathrm{C}\right)$ provided the lowest M:P for cheese. It also modified the initial mode of casein micelle aggregation during gel formation, and increased the rate of bond rearrangement in the formed gel, leading to higher values for fracture stress and storage modulus. We propose that application of the higher coagulation temperatures would prevent the softening of the long-ripened Iranian White cheese.

\section{REFERENCES}

AOAC. 1997. Official Methods of Analysis. 16th ed. 3rd rev. Association of Official Analytical Chemists, Arlington, VA.

Azarnia, S., M. R. Ehsani, and S. A. Mirhadi. 1997. Evaluation of the physicochemical characteristics of the curd during the ripening of Iranian Brine cheese. Int. Dairy J. 7:473-478.

Castillo, M., J. A. Lucey, and F. A. Payne. 2006. The effect of temperature and inoculum concentration on rheological and light scatter properties of milk coagulated by a combination of bacterial fermentation and chymosin. Cottage cheese-type gels. Int. Dairy J. 16:131-146.

Carić, M. 1993. Ripened cheese varieties native to the Balkan countries. Pages 257-276 in Cheese: Chemistry, Physics and Microbiology, Vol. 1. 2nd ed. P. F. Fox, ed. Chapman and Hall, London, UK.

Dalgleish, D. G. 1993. The enzymatic coagulation of milk. Pages 69100 in Cheese: Chemistry, Physics and Microbiology, Vol. 1, 2nd ed. P. F. Fox, ed. Chapman and Hall, London, UK.

Drake, M. A., W. Herrett, T. D. Boylston, and B. G. Swanson. 1996. Lecithin improves texture of reduced fat cheeses. J. Food Sci. 61:639-642.

Ehsani, M. R., S. Azarnia, and A. R. Allameh. 1999. The study of the transfer of nitrogen materials, phosphorus, calcium, magnesium, and potassium from the curd into brine during the ripening of Iranian white brined cheese. Iranian J. Agric. Sci. 30:11-17.

Esteves, C. L. C., J. A. Lucey, D. B. Hyslop, and E. M. V. Pires. 2003. Effect of gelation temperature on the properties of skim milk gels made from plant coagulants and chymosin. Int. Dairy J. 13:877-885.

Fox, P. F., T. P. Guinee, T. M. Cogan, and P. L. H. McSweeny. 2000. Starter culture. Pages 54-97 in Fundamentals of Cheese Science. Aspen Publishers, Inc., Gaithersburg, MD.

Green, M. L. 1990. The cheese making potential of milk concentrated up to four-fold by ultrafiltration and heated in the range $90-97^{\circ} \mathrm{C}$. J. Dairy Res. 57:549-557.

Green, M. L., D. G. Hobbs, S. V. Morant, and V. A. Hill. 1978. Intermicellar relationships in rennet-treated separated milk. II. Process of gel assembly. J. Dairy Res. 45:413-422.

Gunasekaran, S., and M. M. Ak. 2003. Cheese rheology and texture, CRC Press LLC, Boca Raton, FL. 
Hayaloglu, A. A., M. Guven, and P. F. Fox. 2002. Microbiological, biochemical and technological properties of Turkish White cheese 'Beyaz Peynir'. Int. Dairy J. 12:635-648.

International Dairy Federation (IDF). 1997. Bovine rennets: Determination of total milk clotting activity. Standard 157A. IDF, Brussels, Belgium.

Kaya, S. 2002. Effect of salt on hardness and whiteness of Gaziantep cheese during short term brining. J. Food Eng. 52:155-159.

Khosroshahi, A., A. Madadlou, S. M. Mousavi, and Z. E. Djome. 2006. Monitoring the chemical and textural changes during ripening of Iranian White cheese made with different concentrations of starter. J. Dairy Sci. (accepted)

Lemay, A., P. Paquin, and C. Lacroix. 1994. Influence of microfluidization of milk on Cheddar cheese composition, color, texture, and yield. J. Dairy Sci. 77:2870-2879.

Lomholt, S. B., and K. B. Qvist. 1997. Relationship between rheological and degree of $\kappa$-casein proteolysis during renneting of milk. J. Dairy Res. 64:541-549.

Lucey, J. A., M. E. Johnson, and D. S. Horne. 2003. Perspectives on the basis of the rheology and texture properties of cheese. J. Dairy Sci. 86:2725-2743.

Madadlou, A., A. Khosroshahi, and M. E. Mousavi. 2005. Rheology, microstructure and functionality of low-fat Iranian White cheese made with different concentrations of rennet. J. Dairy Sci. 88:3052-3062.

Pastorino, A. J., R. I. Dave, C. J. Oberg, and D. J. McMahon. 2002. Temperature effect on structure-opacity relationship of nonfat Mozzarella cheese. J. Dairy Sci. 85:2106-2123.
Paulson, B. M., D. J. McMahon, and C. J. Oberg. 1998. Influence of sodium chloride on appearance, functionality, and protein arrangement in nonfat Mozzarella cheese. J. Dairy Sci. 81:20532064.

Rudan, M. A., D. M. Barbano, J. J. Yun, and P. S. Kindstedt. 1999. Effect of fat reduction on chemical composition, proteolysis, functionality, and yield of Mozzarella cheese. J. Dairy Sci. 82:661-672.

Russ, J. C. 2005. Image analysis of food microstructure. CRC Press, Boca Raton, FL.

Steffe, J. F. 1996. Rheological methods in food process engineering. 2nd ed. Freeman Press, E. Lansing, MI.

Tunick, M. H. 2000. Rheology of dairy foods that gel, stretch, and fracture. J. Dairy Sci. 83:1892-1898.

Vétier, N., S. Banon, V. Chardot, and J. Hardy. 2003. Effect of temperature and aggregation rate on the fractal dimension of renneted casein aggregates. J. Dairy Sci. 86:2504-2507.

Wium, H., K. R. Kristiansen, and K. B. Qvist. 1998. Proteolysis and its role in relation to texture of Feta cheese made from ultrafiltered milk with different amounts of rennet. J. Dairy Res. 65:665-674.

Wium, H., P. S. Pedersen, and K. B. Qvist. 2003. Effect of coagulation conditions on the microstructure and the large deformation properties of fat-free Feta cheese made from ultrafiltered milk. Food Hydrocoll. 17:287-296.

Wium, H., and K. B. Qvist. 1998. Effect of rennet concentration and method of coagulation on the texture of Feta cheeses made from ultrafiltered bovine milk. J. Dairy Res. 65:653-663. 